\title{
Emigrations from the Crimea to the Ottoman Empire during the Crimean War
}

\section{Hakan Kirimli}

To cite this article: Hakan Kirimli (2008) Emigrations from the Crimea to the Ottoman Empire during the Crimean War, Middle Eastern Studies, 44:5, 751-773, DOI: 10.1080/00263200802315778

To link to this article: https://doi.org/10.1080/00263200802315778

Published online: 11 Sep 2008.

Submit your article to this journal $\sqrt{6}$

Џll Article views: 318 


\title{
Emigrations from the Crimea to the Ottoman Empire during the Crimean War
}

\author{
HAKAN KIRIMLI
}

Throughout the fifteenth - eighteenth centuries, the Crimean Khanate (supported by its close ally, if not suzerain, the Ottoman Empire) constituted one of the major powers of East European politics. The territory of the khanate comprised, in addition to the Crimean peninsula itself, the vast steppes north of the Black Sea, extending from Besarabia to the North Caucasus. In that, its location ensured the 'Ottomanness' of the Black Sea and, playing the role of an effective bulwark, blocked the southward drive of the Russian Empire. Therefore, not surprisingly, the expansionist schemes in the Russian Empire in the eighteenth century, if not earlier, considered the obliteration of the Crimean Khanate and the acquisition of its territories indispensable. Such was the famous, or rather infamous, 'Greek Project' of Catherinian times which aimed at the establishment of Russian domination over the Black Sea and the foundation of a Russian-led 'Greek' empire centred in Constantinople. ${ }^{1}$ Among other considerations, the Crimean peninsula was an ideal stepping stone for further expansionist designs involving the eventual conquest of Constantinople, or Tsargrad, as it was called by many Slavs. The obvious strategic, military and economic importance and potential of the Crimea, along with its exotic beauties, led many a tsarist statesman to dream of the Russification of the peninsula and its hinterland.

Thus, when, after some 15 years of war and bloody unrest, the Russian Empire finally dissolved the Crimean Khanate and annexed its territories, resolute measures were taken by the tsarist government to this effect. From the very beginning of Russian rule in the Crimea in 1783, there was a determined effort on the part of the tsarist state to colonize the peninsula with Russian/Slavic (or at least Christian settlers), an enterprise during which the Crimean Tatars, the native people of the Crimea, were seen as superfluous, to say the least. The centuries-long political and military enmity between Russia and the Crimea was by no means forgotten. In fact, during the first 70 years of Russian rule in the Crimea preceding the Crimean War, at times, a considerable deal of oppression was meted out to the Crimean Tatars. The latter essentially became second class subjects in virtually all aspects of social and economic life in the peninsula.

Therefore, the Russian annexation of the Crimea in 1783 signalled more than the loss of their age-old independence for the Crimean Tatars; it was also the beginning of a long and continuous process of their emigration to the Ottoman Empire, the land of their religious and ethnic kinsmen, in response to the tsarist policies and 
practices. These emigrations would literally drain the Crimean Tatar population off the peninsula and its hinterland well up to the Soviet times. ${ }^{2}$ By and large, these emigrations were considered by the tsarist authorities as a blessing which would cleanse the newly-conquered land of an undesirable population. The RussoOttoman wars which took place once in almost every two decades during the eighteenth and nineteenth centuries played an important role in such emigrations. During these wars, the Crimean Tatars were considered by most Russian officials as a 'fifth column' of the Ottoman Empire. Although most Crimean Tatars were sympathetic toward their kinsmen in Turkey, no revolts on their part during the wars were ever recorded. Still, in many wartime cases, very severe measures were taken to control this potentially 'unreliable' element. During the Russo-Ottoman War of 1806-12, the deportation of a large portion of the Crimean Tatars was considered, and actually, though partially, was applied. ${ }^{3}$ Not surprisingly, the Crimean Tatar emigrations usually gained momentum immediately after the various Russo-Ottoman wars.

The war of 1853-56, whose main theatre was in the Crimean peninsula itself, was no exception. Though it began as a war between the Ottoman and Russian Empires, a year later Britain, France, and Sardinia joined the Ottoman Empire. The circumstances for a very substantial wave of Crimean Tatar emigration were created during the course of the war. With the outbreak of the war (which for a year took place far away from the Crimean peninsula), the Crimean Tatars were, as usual, viewed by the Russian authorities as a potentially treacherous population. The opinion voiced in many tsarist circles about the 'inimical spirit' of the Crimean Tatars towards the Russians and about a possible uprising of the former in which the lives and properties of the Christian population in the Crimea would be endangered were conveyed to Tsar Nicholas I himself. In November 1853, upon the orders of the tsar inquiries were undertaken in the Crimea about the veracity of such hearsay and about the presence of Turkish emissaries in the Crimea. ${ }^{4}$ In his report on 29 November 1853, Lieutenant-General Vladimir Ivanovich Pestel, the Civil Governor of Tauride who did not share with other Russian officeholders the feelings of aversion toward the Crimean Tatars, disagreed with the allegations. He stated that he could not possibly have failed to notice the spirit of which the Crimean Tatars had been accused throughout his nine-year service in the capacity of governor had it ever existed. He added that there were harmful tattlers not only among the Crimean Tatars but also among the Christian population; in any case he was taking the necessary measures against any kind of possible disorder. According to LieutenantGeneral Pestel, the mood of the Crimean Tatars might have changed only in the case of the appearance of the Turkish army on the Russian borders or on the Russian shores, an occurrence which he considered an impossibility. ${ }^{5}$

At any rate, with the out-break of the war, strict surveillance was applied over the Crimean Tatars in the Crimea. ${ }^{6}$ General Aleksandr Sergeevich Menshikov, the Commander-in-Chief of the Russian forces in the Crimea, was particularly distrustful of the Crimean Tatars. He issued orders for the 57th regiment of the Don Cossacks to control the activities of the Crimean Tatars and to cordon the seashore from Perekop (Orkap1) to Sevastopol in June 1854. Other units were tasked with surveying the Crimean Tatars on the southern shore of the peninsula as well as in the mountainous region. ${ }^{7}$ The Cossacks around Kezlev (Yevpatoriia) under the 
command of Maksimovich played a notorious role in harassing Crimean Tatars in the district. They were reported to have been involved in threatening, beating, and robbing the Crimean Tatar peasants and violating women in the area, and were responsible for the killing of seven Crimean Tatars in a village. ${ }^{8}$

On 13 September 1854, the Allied navy anchored off Kezlev. The Allied command gave the inhabitants of the town the choice of staying there or leaving it within 24 hours. Lacking sufficient forces for any effective defence, the town authorities surrendered and a small Allied force occupied Kezlev. ${ }^{9}$ The main Allied army (French, British, and Ottoman) landed on the Crimean peninsula near Lake Kamışl, just south of Kezlev, on 14 September. Having completed the disembarkation of the bulk of the army within a few days, the Allied forces marched southwards toward the Russian naval base of Sevastopol, which became the focal point of military action during the Crimean War.

Initially, the Allied force which occupied Kezlev was a meagre one. A British marine force of about 450 was complemented by 300 French and 200 Turks, as well as an additional 100 British within two weeks. ${ }^{10}$ As one Russian official stated to the Allied authorities during the process of surrendering, the inhabitants of Kezlev were very badly off for food and the Crimean Tatar population was almost starving. ${ }^{11}$

By all accounts, in Kezlev, as well as other areas under Allied occupation, the Crimean Tatars were clearly sympathetic to the Allies. ${ }^{12}$ There is no doubt, the presence of the Turks among the Allies was a major reason for such a demeanour, but the oppressive policies undertaken by the Russian authorities during the war also played an important role. Not surprisingly, when the British commander in Kezlev, Captain Thomas Saumarez Brock, organized a local police force to keep order soon after the occupation of the town, he turned to the Crimean Tatars and appointed Soqur Osman Ağa ('Osman Ağa the Blind'), who had held a similar post under Russians, in charge of it. ${ }^{13}$

This mounted police or militia initially consisted of some 800 Crimean Tatars. ${ }^{14}$ During the ensuing months their numbers reached around 2,000. Since the town defences and the outposts of the Russians were quite close to each other, there was little space left in between for the Crimean Tatars to graze their herds. Therefore, one of the urgent tasks of the Crimean Tatar mounted militia was to prevent the Cossacks from carrying away the herds and flocks of the people living around the town and bringing cattle into the Allied-occupied area. ${ }^{15}$ Although this Crimean Tatar militia was very poorly armed (with 'scythes set on poles, and rude fir lances, with knives for spear-heads, and some few flint muskets'), they were reported to fight with a great deal of courage and determination and were successful in fulfilling their duties. ${ }^{16}$ During the first months of the Allied occupation of Kezlev, when there was an insufficient number of Allied troops available to protect the town, the Crimean Tatar militia actively participated in staving off various assaults by the Cossacks. ${ }^{17}$ Therefore, especially in those times, the Crimean Tatar militia played a critical role in maintaining the safety of the town both internally and externally. It is noteworthy that Russian institutions and property in Allied-occupied Kezlev was also safeguarded by the Crimean Tatar militia. ${ }^{18}$ In Kezlev and in other occupied areas, the Crimean Tatars were in general friendly to the Allies, and readily offered, hired or sold them carts, animals, and foodstuffs. ${ }^{19}$ There were also several Crimean Tatar 
individuals who served in, or collaborated with, the Allied armies by performing reconnaissance and intelligence duties. ${ }^{20}$

As acknowledged in Russian eyewitness accounts, the sympathies of the Crimean Tatars toward the Allies (especially toward the Turks), were not transformed into an unleashed rage against the Russian population in the Allied-occupied lands. This was true both inside the town of Kezlev and in the countryside. ${ }^{21}$ Although there were cases of some Tatar bands in the hinterland who threatened, robbed and beat certain pomeshchiki (landlords), in most cases such acts were admittedly directed against those who had been particularly oppressive against the Crimean Tatar peasants during peacetime. ${ }^{22}$ Even these occurrences were of an exceptional and individual nature. F. Stulli, a Russian resident of Kezlev, testified that all the hearsay about such 'Tatar terror' was greatly exaggerated and no cases of killings, apprehensions, or open pillaging against the Russians took place in Kezlev. He praised the behaviour of the Crimean Tatars toward Russians during those days. ${ }^{23}$ General Eduard Todleben, the hero of Sevastopol, wrote that when the Russian noblewomen and children, together with all their belongings, were evacuated from Sevastopol on 2 October 1854, this task had been carried out mostly by Crimean Tatar guides and horses. During this difficult mission none of the Russians were harmed, and they were safely taken to Simferopol (Akmescit) and even further. ${ }^{24}$

When combined with the ever-existent suspicions, if not overt aversion of certain Russian authorities, the Crimean Tatars' manifestation of sympathies towards the Allies led to the contemplation of severe measures against them. On 11 October 1854, General Menshikov ordered Lieutenant-General Pestel to deport all the Crimean Tatars on the Black Sea littoral from Perekop to Sevastopol and to confiscate all animals of the Crimean Tatars who had contacts with the enemy. He repeated his orders on 12 October 1854 that the deportation of the Crimean Tatars should not be delayed in any way. ${ }^{25}$ The Crimean Tatars were to be resettled in the mainland of the Tauride guberniia, and if this proved to be impossible, further inland, in the Yekaterinoslav and Kherson guberniias. There were even suggestions, such as the one from the renowned scholar Peter Köppen, that they be resettled in the Semipalatinsk oblast' in the Kyrgyz (Kazak) steppes. Another Russian statesman, V.M. Kniazhevich deemed it imperative to 'cleanse all the [Crimean] littoral and port cities from them'. ${ }^{26}$ These extreme measures were not implemented only because such a mass deportation would have crippled the transportation of Russian troops to the front. ${ }^{27}$

Following the Allied landings on the Crimean shores, Cossack units, especially those around Kezlev were given a free hand over the Crimean Tatar peasants there whom they terrorized to the utmost. As one Russian general, Grigorii Levitskii, recorded, the Cossacks would stop the Crimean Tatar peasants they encountered and would extract money from them by accusing them of going to the enemy. In case of refusal, the hapless peasants would be taken to the Russian army headquarters and charged with desertion or treason. When a Crimean Tatar left his village to fetch water, he might well be subjected to this treatment if he refused to pay the bribe the Cossacks demanded. When taken to headquarters, there was almost no chance to persuade the authorities as to their innocence, because in the eyes of most of the latter all Crimean Tatars were actual or potential traitors. Thus, many Crimean Tatars charged with treason were jailed and exiled to the guberniias of Kursk, 
Yekaterinoslav, Kherson, Poltava, and Orel. ${ }^{28}$ Several Crimean Tatar mirzas (noblemen) were also arrested and exiled on the same charges. ${ }^{29}$ On the pretext of preventing them from falling into the hands of the enemy, the cattle of the Crimean Tatars living in the vicinity of the seashore were driven off to the interior of the peninsula. ${ }^{30}$ In fact, the 'transportation' of cattle was outright plunder. According to General Todleben, Cossacks carried off 40,000 cattle, the primary means of livelihood, from the Crimean Tatars living around the Kezlev region. ${ }^{31}$ Moreover, the Crimean Tatars on the entire Crimean seashore were forced to move at least 25 versts $^{32}$ away from the seashore. ${ }^{33}$

As a direct consequence of these oppressive measures and abuses in the countryside, thousands of Crimean Tatars began to flee not only from the nearby villages but from most of the uezd (district) of Kezlev and take refuge in the Alliedoccupied Kezlev. ${ }^{34}$ While one source gives the number of the Crimean Tatar refugees in Kezlev during the Crimean War as $10,850,{ }^{35}$ according to General Todleben there were about 20,000 of them. ${ }^{36}$ The peacetime population of Kezlev had been estimated as 13,340 in the early $1850 \mathrm{~s} .{ }^{37}$ The influx of refugees to the town started with the first arrival of the Allied forces and continued almost incessantly. Provisioning them with food and finding shelter for them proved to be a major problem for the Allied authorities. Though the Allies offered the refugees a certain amount of their rations, this was not sufficient to alleviate their needs. ${ }^{38}$ Inevitably, epidemics, especially cholera, emerged among the refugees. At one point in October 1854, the death toll among them reached 40-70 people daily. Providing fuel for them was another problem. ${ }^{39}$ Although some of the able-bodied among the refugees were employed by the Allies, particularly by the Turks, the vast majority of them remained without any means to subsist, as they consisted of women, children, and the elderly. ${ }^{40}$ Some of those employed by the Allies were taken to work near Sevastopol. There, many of them, together with their families, suffered from insufficient food and shelter. ${ }^{41}$ Returning to their homes in the Russian-held zone did not seem to be an option for most refugees. The treatment by Russian LieutenantGeneral Baron Korff's troops of the returning refugees was hardly encouraging: they would be whipped and deported to the north from the Crimean peninsula. ${ }^{42}$ There were also accounts of cases in which the Cossacks shot returning refugees. ${ }^{43}$ Even after the assurances of General Menshikov that those returning by 1 December 1854 would be pardoned, very few of them did so. ${ }^{44}$

The movement of Crimean Tatar refugees into Allied-occupied Kezlev was a precursor to the impending wave of emigration to the Ottoman Empire. Actually, the exodus of Crimean Tatars from the countryside to Kezlev must have been accelerated by the fact that a large number of Ottoman troops were deployed in the town. The arrival of new Turkish forces began in late November 1854, and on 10 December they were augmented by a division transferred from the Danubian front. ${ }^{45}$ By the end of February 1855, some 41,000 Ottoman troops had been transported to Kezlev from the Balkans. Ömer Pasha, the Commander-in-chief of the Ottoman army, was also there. ${ }^{46}$ Not surprisingly, relations between the Ottomans and the Crimean Tatars in Kezlev were very cordial from the start. Already in October 1854, the Muslim clergy of Kezlev had declared their loyalty to the Ottomans. ${ }^{47}$ With the deployment of the main Ottoman army, collaboration between the Ottomans and the Crimean Tatars increased. On 17 February 1855, a Russian army under the 
command of General Stepan Aleksandrovich Khrulev launched a major offensive to capture Kezlev. In the ensuing battle of Kezlev (Yevpatoriia), the Ottomans inflicted a major defeat upon the Russians. During this battle, which was one of the critical engagements in the war, many Crimean Tatar volunteers fought side-by-side with the Ottoman troops, where the casualties of the former were 13 dead and 24 wounded. ${ }^{48}$ In March 1855, upon the proposal of Ömer Pasha, the Sultan sanctioned the formation of a special cavalry regiment composed of some 300 Crimean Tatar volunteers within the Ottoman army. ${ }^{49}$ By then, the French had already accepted some 150 Crimean Tatar volunteers into their army. ${ }^{50}$ The Ottomans also established a local administration for the day-to-day affairs of the Crimean Tatars in Kezlev. ${ }^{51}$

During the Crimean War, only a fraction of the Crimean peninsula was occupied by the Allies, including the town and immediate surroundings of Kezlev, the strip of seashore from Kezlev to Sevastopol, the terrain around Sevastopol, the port of Balaklava and part of the Baydar valley, as well as the towns of Kerch and Yenikale. The relations between the Allies and the Crimean Tatars in these territories were similar to those in Kezlev. During the one-year-long siege of Sevastopol, many Crimean Tatars who lived, or happened to be, in the vicinity had friendly relations with the Allies, and many of them were hired by the Allies as cart drivers, labourers, guides, etc. ${ }^{52}$ In some cases, as happened in the Balaklava region, local Crimean Tatars would be seized by the Allies who kept them under guard and paid them to work. ${ }^{53}$ When General Fitzroy Somerset Lord Raglan, the Commander-in-Chief of the British forces, soon after the occupation of the area by the latter, ordered the expulsion of the Greeks around his headquarters in Balaklava, he allowed the Crimean Tatars to remain. ${ }^{54}$ Although not comparable to the case in Kezlev, several Crimean Tatars in the Russian-held interior fled to the Allied-occupied lands around the south-western tip of the Crimean peninsula. ${ }^{55}$ Deeply suspicious of the proAllied sympathies of the Crimean Tatars in the Baydar valley and its surroundings, the Russian authorities took stern measures to prevent their contacts with the Allies. The wartime restrictions for the inhabitants of the villages of Kikineiz, Küçükköy, Limena, Simeiz, Mşatka, and others located in the area included the ban on leaving their villages and keeping contact amongst themselves and with the outside world. They were also forced into resettlement in other places. ${ }^{56}$

During the Allied amphibious operation in Kerch and Yenikale on 24 May 1855, they found the local Crimean Tatars ready to fraternize, particularly with the Turks. ${ }^{57}$ In fact, as Kerch was evacuated by the Russian army, many Crimean Tatars from the countryside rushed into the city before the Allied forces. Some of these Crimean Tatars were reported to have been involved in the cases of plundering along with the Ottoman and French soldiers. ${ }^{58}$ From 7 June 1855 on, the command of Kerch and Yenikale was delegated to the Ottoman army. ${ }^{59}$

The emigration of the Crimean Tatars to the Ottoman Empire started soon after the Allied landing on the Crimean peninsula. This first wave was nothing other than an emergency measure to evacuate the starving and suffering refugees in Kezlev. After all, given the militarily precarious situation of Kezlev, under the constant threat from the nearby Russian forces, keeping and feeding large numbers of refugees was inexpedient for the Allies. Already on 30 December 1854, the English Commissariat Officer stationed in Kezlev sought permission to evacuate some of the 
Crimean Tatar refugees in the town 'who were anxious to leave, and were in a most destitute condition' by any transports to Varna. ${ }^{60}$ Conveying this proposal to Stratford de Redcliffe, the British Ambassador to the Sublime Porte, Rear-Admiral Sir Edmund Lyons stated,

On the one hand, I feel that the poor Tatar population of the Crimea, who have incurred the displeasure of the Russian Government in consequence of their adherence to the cause of the allies, deserve my consideration; but, on the other hand, I do not know how far I should be justified in sending a number of paupers to the Ottoman dominions. ${ }^{61}$

During the first half of 1855 , the Ottomans faced the imminent refugee issue from the Crimea. There is no doubt, during the last months of 1854, some individual or small groups of Crimean Tatar refugees must have been sent from Kezlev to the Ottoman Empire. The Ottoman authorities were cognizant of the fact that, after the end of the war, concomitant with the issue of exchanging prisoners-of-war there would emerge the problem of returning or accepting the subjects of the belligerent countries. During the discussion of the matter at the Porte, it was stated that while the Ottoman subjects from the Danubian lands who fled to Russia would be treated magnanimously upon their return to the Ottoman Empire, such a fate could not be expected for those Russian subjects (i.e., mostly the Crimean Tatars) who sought refuge in the Ottoman army and deserters and defectors from the Russian army. Therefore, the Porte concluded that they should not be returned to Russia against their will and ordered its officials to inquire about their numbers and intentions. ${ }^{62}$

Apparently, the first substantial groups of Crimean refugees from Kerch and Yenikale began to arrive in Ottoman lands soon after Ottoman troops landed there in late May 1855, although individuals from the Kezlev or Balaklava/Baydar regions had certainly gone to the Ottoman domains before that date. All evidence suggests that the earliest company of refugees from Kerch/Yenikale (220 people) arrived in Istanbul in mid-June 1855. Upon the orders of the Sultan, every one of them was provided lodging, daily pay, and soap. ${ }^{63}$ The refugees from Kerch continued to arrive during the following months. Interestingly, they did not consist only of the Crimean Tatars; among them were also Jews and Poles. While the motives of the Polish refugees could be attributed to the anti-Russian sentiments prevalent among many Poles then, those of the Jews who left Russian rule were not clear in the documents. As their names testified, most, if not all of them, were European (i.e. non-Crimean) Jews. ${ }^{64}$

In late September 1855, 80 Jewish families from Kerch, all of whom were citizens of Austria, were temporarily settled in the Beyoğlu (Pera) quarter in Istanbul. It is possible that they constituted all of the Jewish refugees from Kerch by then. In a petition to the Ottoman government, they stated that although they had been assigned a daily stipend, there were irregularities in this payment. ${ }^{65}$ There were some among the refugees from Kerch who, upon facing misery in Istanbul, intended to return to Kerch instead of being settled in Rumelia; 113 such people applied to the Ottoman authorities in October 1855, requesting to be allowed to return. Their request was not only granted but they were offered financial support from both the Ottoman government and from the embassies of Britain and France in Istanbul. ${ }^{66}$ 
Though the nationalities of these refugees were not specified in the Ottoman documents, in all likelihood some or all of them were Jews and/or Poles.

The refugees from Kerch and Yenikale were only a fraction of the emigrants who poured into the Ottoman Empire during and immediately after the Crimean War. The bulk of them would leave the Crimea from the two main centres of Allied occupation (except for Sevastopol), i.e., Kezlev and the Balaklava/Baydar areas.

Until the end of the war and the signing of the peace treaty, it seems that the Porte did not realize that what was in store might be the mass exodus of Crimean Tatars to the land of the Sultan. At any rate, by then, the people going to Turkey were relatively few in number and they were still in the status of individual refugees who left the Crimea to escape from hunger or political repression. The Ottomans treated or viewed many of them as temporary fugitives who would return to their homelands when the war ended, or when the circumstances changed for the better. This was the case with the 93 Crimean Tatars who arrived in Rusçuk in November or December 1855. They had collaborated with the Ottoman army in the Crimea and travelled to the Ottoman Empire upon the understanding of the Commander-in-Chief, Ömer Pasha. The Porte was initially irresolute about the procedure to deal with those who wished to come to the Ottoman Empire. Clearly, the Ottoman authorities were not certain whether these refugees would be temporary refugees or permanent residents in the Ottoman Empire. Still, since it would have been inappropriate to refuse these unfortunate people, they would be given a certain amount of money and/or rations during their stay in the country. ${ }^{67}$ The need for a clear-cut policy and guidelines for handling the issue of emigration from the Crimea was obvious on the part of the Ottoman authorities.

With the treaty signed by the belligerent powers in Paris on 30 March 1856, the hostilities ended. Article V of the Treaty stipulated that

Their Majesties the Queen of the United Kingdom of Great Britain and Ireland, the Emperor of the French, the Emperor of all the Russias, the King of Sardinia, and the Sultan, grant a full and entire amnesty to those of their subjects who may have been compromised by any participation whatsoever in the events of the war in favour of the cause of the enemy.

It is expressly understood that such amnesty shall extend to the subjects of each of the belligerent parties who may have continued, during the war, to be employed in the service of one of the other belligerents. ${ }^{68}$

Evidently, this article of the Treaty of Paris did not prove effective enough to assuage the Crimean Tatars who were deeply apprehensive of prospective Russian reprisals and punitive measures upon recovery of the Allied-occupied lands. Rumours circulated in Kezlev that the Russian government was planning to deport the Crimean Tatars to the province of Kazan soon after the departure of the Ottoman troops. In April 1856, conveying these rumours, the Muslim clergy of Kezlev stated to the Ottoman military authorities there that, if they would be allotted places of settlement in the Dobruja region, most of the Crimean Tatar population in the town was ready to emigrate. Among the potential emigrants was the entire staff of the Tatar Regiment formed from among the Crimean Tatars in Kezlev. ${ }^{69}$ Upon the examination of the issue, in late April 1856, the Porte resolved that turning down 
such a request would be incompatible with the magnanimity of the Sultan, and, since the emigrants would be leaving all their properties there, they should be granted aid and tax exemptions, irrespective of their religion and origin. They would be given free land to settle and cultivate, as well as seeds and draft animals. On the other hand, it was deemed inappropriate to encourage the people in Kezlev to emigrate by publicizing this resolution and the clergy and a few other people should be informed of this only privately. ${ }^{70}$

This cautious approach of the Porte in not-so-publicly inviting immigrants was taken obviously in view of the international, especially Russian, spectators. Otherwise, at the time, Ottoman statesmen generally favoured increasing in population (especially its Muslim component) in the empire through migration from abroad. ${ }^{71}$ Not surprisingly, the commander of the Ottoman troops in Kezlev, Ahmed Pasha, praised the 'good intentions' (niyet-i hasene) of the Crimean Tatars who were about to emigrate to the Ottoman Empire and reproached the attempts of certain people coming from the Russian side to deflect them from the 'true path'.

The exodus of the Crimean Tatars was seen as a blessing by many tsarist officials, above all the tsar himself. Upon a report about the matter, Tsar Alexander II stated that he did not find any reason to hinder the covert or even overt emigration of the Crimean Tatars to Turkey, writing 'on the contrary, under the current circumstances, the occasion of voluntary emigration should be considered highly favourable for the deliverance of the land from this harmful people'. This comment of the tsar was conveyed to the Governor of the Tauride guberniia in June $1856 .^{72}$ Accordingly, the local authorities were ordered to accelerate the departure of the Crimean Tatars and not to delay the issuing of their passports. The Crimean Tatars, understandably, took all these developments as further evidence that they were unwelcome in the Russian state, a fact which certainly exacerbated the already existent stir for emigration. The abuses of various local officials and landowners who benefited from the departure of the Crimean Tatars also contributed to the movement for emigration. Various types of swindlers also came to the Crimea from Russia to take advantage of the situation. General Todleben blamed these nefarious individuals for spreading rumours that Crimean Tatars would soon be deported to the inner provinces, converted to Christianity, conscripted into the army, etc. ${ }^{73}$

The Ottoman government, receiving reports describing the situation in the Crimea, saw the writing on the wall and recognized that a flow of Crimean Tatar refugees and emigrants was imminent. The Porte considered having them sent from Kezlev directly to the harbour of Balçık in southern Dobruja, whence they would later be settled in various parts of Ottoman Rumelia. As explained above, having been keen on not giving the impression that it was eagerly or purposefully carrying away the people from the Crimea to Turkey, the Porte resolved to embark the refugees in the vessels which brought back the Ottoman soldiers, instead of sending special vessels for their transportation. This was intended to give the appearance that the Crimean emigrants were simply joining the returning Ottoman troops on their own individual will without any official involvement of the Ottoman government. In this fashion, while two-thirds of the space of each vessel would be allocated to refugees and their belongings, only the remaining one-third was to be spared for the evacuating troops. During the journey, the refugees would be supplied with rations 
along with the soldiers, and they would be disembarked in Balçık, before the ships proceeded to the main destination of the troops. Upon their landing on Balç1k, the emigrants would be sent to their places of settlement in Rumelia. During their stay in Balçık, they would be provided with army tents for shelter and continue to receive rations for some 20 days. ${ }^{74}$ The Ottoman government was also anxious to have the refugees shipped out of the Crimea before the ratified versions of the Treaty of Paris was exchanged between the Powers. ${ }^{75}$

The Crimean Tatars continued to leave their homeland together with the evacuating Allied troops. The last Ottoman soldier left Kezlev on 23 May 1856, while the remaining French squadron departed a week later. ${ }^{76}$ Although at the moment of the evacuation of the French from the town, the spread of the news among the Crimean Tatars that they had been granted amnesty by the tsar and the return from Turkey of a few refugees seemed to halt the exodus, ${ }^{77}$ it was to continue in the ensuing months. In the process, whole villages were vacated or were left with few families. ${ }^{78}$ On 11 May 1856, Ahmed Pasha gave the number of Crimean Tatars who had left Kezlev with the departing Ottoman troops for Balçık as 7,683, in addition to some 1,300 people who had left Kezlev for other places where they wished to settle. The pasha expected around 1,500 people from Kezlev by the final departure of the last Ottoman soldiers. ${ }^{79}$ According to another official Ottoman document, however, 7,582 Crimean Tatars from Kezlev and its surroundings had arrived in Balçı by the first week of June $1856 .{ }^{80}$ The difference between these two figures is difficult to explain.

The Allied troops evacuated Yenikale on 20 June, and Kerch on 22 June $1856 .{ }^{81}$ As of the first week of June 1856 (i.e., within a year after the Allied occupation), the total number of refugees from Kerch who were eventually or directly sent to the Ottoman Rumelia (i.e., excluding those who were in Istanbul or other places) was 1,319. While the bulk of them (1,202 people) were Crimean Tatars, 64 of them were Jews and 53 were Poles. ${ }^{82}$ The ranks of the Crimean Tatars from Kerch included also some Nogays who had crossed the Kerch Strait from Taman to join the emigrants to Turkey. ${ }^{83}$ In the face of the mixed religious character of the emigrants from Kerch, strict orders were issued from Istanbul providing for the equal treatment of the Christian and Jewish emigrants with the Muslims upon their arrival in Balçik and thereafter. ${ }^{84}$

The Allies left the harbour of Balaklava on 12 July $1856 .{ }^{85}$ This spot was an important outlet for the refugees/emigrants especially from its hinterland, the Baydar valley, to the Ottoman Empire. The Crimean Tatars of Baydar were very much agitated in anticipation of possible Russian reprisals, particularly on the part of the Greek Balaklava battalion and the Cossacks who were known to have strong anti-Tatar sentiments. The killing of a Cossack and a peasant in April 1856 only exacerbated these fears. ${ }^{86}$ Thus, throughout April and May 1856, the Crimean Tatars from the Baydar valley were busy leaving their villages for the Ottoman ships waiting for them in the harbour of Balaklava, watched by Russians who were glad to get rid of them. ${ }^{87}$ An Ottoman document listed 4,469 Crimean Tatars who left the Baydar region for the Ottoman Empire as of the first week of June $1856 .{ }^{88}$ The Crimean Tatar exodus from Balaklava was to continue for the months to come. Consequently, almost the entire Baydar valley and the surroundings of the cape of Foros were emptied. ${ }^{89}$ 
According to an official Ottoman figure, a total of 13,370 Crimean Tatar refugees/ emigrants had arrived at the harbour of Balçı as of the first week of June $1856 .{ }^{90}$ Their number reached around 13,600 by late June $1856 .{ }^{91}$ These figures did not include those who sailed to Istanbul or other places and stayed there. Moreover, like the above-mentioned figures of Ahmed Pasha, there were higher Ottoman data for the same cases. The refugees/emigrants continued to leave the Crimea after the evacuation of the Allied troops too. Throughout the second half of 1856, several individual groups of Crimean Tatar emigrants arrived in Ottoman territories. ${ }^{92}$ Individually or in relatively small groups, Crimean Tatar emigrants continued to travel to the Ottoman Empire in 1857 too.

The departure of the Crimean Tatars reached a critical mass for becoming a peril to the Crimean economy. Although this was well realized by many local Russians, the tsarist government circles were still rejoicing over the emigration of the Crimean Tatars. In August 1856, Gerngross, the Director of the First Department of the Ministry of State Properties, arrived in the Crimea to supervise the resettlement on imperial lands. At a meeting of the local nobility, he announced that the Emperor considered the departure of the Crimean Tatars a happy occasion for the future of the Crimea, whose development had been retarded for so long. The rhetoric of Gerngross, who openly talked about the uselessness of the Crimean Tatars and stated that their departure should not be hindered, offended some of the Crimean Tatar noblemen in the audience. An indignant Mehmed Bey Bolatukov, one of the leading Crimean Tatar noblemen who was renowned for his loyalty to the tsar and whose father Kaya Bey Bolatukov had been a hero of the war against Napoleon in 1812, commented on Gerngross, saying, 'After this, I have to leave Russia too!" 93 However, upon hearing contrary views of the Russian landowners who were seriously concerned about the economic impact of the emigration of the Crimean Tatars, Gerngross changed his position. He asked the tsarist Crimean administration to scale down the emigration in September 1856. Accordingly, both the GovernorGeneral of Novorossiia and the Governor of Tauride summoned the Crimean Tatars and explained to them that they were not being ousted. Nevertheless, by then, it was already too late. Even many of those present at the governors' meeting left their homeland soon after. ${ }^{94}$

Meanwhile, taking into consideration the number of already arrived and prospective emigrants, the Porte endeavoured to organize and institutionalize the ongoing emigration and resettlement of the emigrants. In any case, from the beginning of the Allied landing on the Crimean peninsula, the refugees from this land had been granted a certain amount of daily pay as an imperial bounty for some time to come, and their expenses of travel and freight from the Crimea and their temporary accommodation in the places where they landed on Ottoman soil were covered by the Porte. Finally, they had also been granted land upon which to resettle. As the influx of the refugees/emigrants culminated with the impending evacuation of the Allied troops in spring 1856, the Ottoman government decided to regulate the issue more systematically. To this effect, an ad hoc commission was formed to examine the matter in Istanbul in April 1856. Specialist officials were assigned to deal with the emigrants on the spot. Included among these officials were a number of Crimean Tatars who had recently immigrated to the Ottoman Empire. $^{95}$ 
Said Pasha, the Governor of the province of Silistre, which included most of the lands considered for settlement as well as the harbour of Balçık, was put in charge of handling the matters of the emigrants as they arrived in Balçık. ${ }^{96}$ Upon orders from Istanbul, in order to oversee the disembarkation and other affairs of the emigrants in person, Said Pasha went to Balçık on 30 April $1856 .{ }^{97}$ Starting the next day, approximately 1,000 emigrants began to land at Balçık every day for the next ten days or so. By 12 May 1856, their numbers had reached $11,100 .^{98}$ The pace of the arrivals slowed down after this point and, as stated above, the total number of emigrants arriving in Balçık would reach around 13,600 as of late June 1856. ${ }^{99}$ During their stay in Balçı the emigrants were provisioned with bread daily. ${ }^{100}$ They had to spend their temporary stay (which would certainly extend to several months at least) in Balçı, mostly in army tents and in any kind of shelters they could find. ${ }^{101}$ Due to the limited space in the small town of Balçı, which was overwhelmed by the influx of emigrants, many of the latter were temporarily accommodated in the towns of Hacioğlupazarcık, Pravadi, Hezargrad (Razgrad), and Şumnu and their villages. ${ }^{102}$ As the weather was exceptionally cold and rainy, the pasha tried hard to accommodate the immigrants in safer shelters than the tents so the women, children, and sick among them would not suffer. ${ }^{103}$ A physician and medicine were brought from the hospitals of Varna to care for the sick. ${ }^{104}$

On 3 May 1856, a detailed list of instructions on handling the affairs of the Crimean migrants was issued to the Governor of Silistre by the Ottoman government. These instructions encapsulated the basic regulations of the acceptance and resettlement of the Crimean migrants in the immediate aftermath of the Crimean War. In fact, they reformulated the practice which had already been exercised since the beginning of the war. In compliance with these regulations, irrespective of their creed, all refugees (migrants) would be granted exemptions from all taxes for a period of ten years, and were freed from military conscription for twenty-five years. For their own benefit and that of the state they would be resettled in fertile lands with sufficient water resources, in settlements not far from each other. In case the immigrants were incapable of building their homes themselves in the villages and towns in which they were settled, the Ottoman government would undertake the job. The local inhabitants were encouraged to give a hand to the immigrants, in the process of their settlement, though this would not be made compulsory. In order to initiate farming by the immigrants, they were to be provided with oxen, carts, and seeds by the state. The amount of this aid was to be determined in accordance with the properties of the lands that would be allocated to them. Those who lived in poverty would be given a certain amount of provisions for subsistence. Since this aid was to be offered as a starting capital to the immigrants, it was expected that, when they reached a sufficient level of wealth, this support would be reimbursed to the state in an unspecified way. The heads of the immigrant villages and counties formed by these villages would be elected by the immigrants living there. ${ }^{105}$ Immigrants who were artisans were settled in towns where they could continue their professions, and were provided with the equipment necessary for their crafts. ${ }^{106}$

The Crimean migrants continued to come to the Ottoman Empire after the exchange of the ratified versions of the Paris Treaty on 27 April 1856. Naturally, they were no longer able to use the vessels belonging to, or rented by, the Allied (basically Ottoman) navy. Embarking on private vessels, they sailed to Ottoman harbours, 
primarily to Istanbul. The travel and freight expenses of those who arrived in Istanbul were paid by the Ottoman government before they were shipped to Balçık for resettlement in Rumelia. ${ }^{107}$ There were also Crimean migrants who sailed directly to the Rumelian harbours (i.e., to Balçık, Varna, etc.) by private vessels during the second half of 1856, and their expenses were reimbursed by the Ottoman government. $^{108}$

Apart from the standard treatment of the Crimean immigrant groups, the Ottoman government also granted special aid and privileges to several individuals. Notably, the Crimean Tatars who had served, or assisted, in the Ottoman or Allied forces actively during the war were treated in a more favourable way. Such persons, usually men of certain local stature, together with their family members and entourages, were granted a lifetime ('until the salvation of their homelands from the enemy rule and their return to there') salary. ${ }^{109}$ Some of them, especially those with experience in the Russian state service, were offered official posts. For example, Abdülveli (Veli) Bey and Mustafa Efendi, a cleric from Kezlev, who had migrated to the Ottoman Empire in early 1856, were employed as state servants to deal with matters concerning the arriving Crimean Tatar immigrants in Balçı. ${ }^{110}$ Said Emin Efendi, who had served in the Allied armies with distinction in the Crimea and who had been decorated by the Ottomans, British, and French, was granted a salary of 1000 kuruş and the title of the Director of Imperial Stables. He was also appointed as the director of one of the districts in which Crimean Tatar immigrants were settled. ${ }^{11}$ Those Crimean Tatars who had served in the Ottoman Imperial Army in the Crimea were granted salaries and employed in similar posts. ${ }^{112}$

The ulema (religious scholars and servants) of Kezlev were also treated in a more favourable way. This was the case not only because they were communal leaders or men of certain societal influence, but unlike other immigrants who were farmers or artisans, they had no practical trade with which to earn their daily bread unless they received a religious post or steady salary. Therefore, in several cases, Crimean Tatar clerics would appeal to the Ottoman government for help as they suffered from economic hardships. By and large, they were treated with respect. When Feyzullah Efendi, the chief Muslim cleric, i.e., the kadl, of Kezlev arrived in Istanbul accompanied by his family and entourage on 14 May 1856, he was officially hosted by the government. ${ }^{113}$ Other clerics from Kezlev were treated by the government in a similar fashion. Hacı Yusuf Efendi, a religious scholar (müderris) originally from Bukhara, and his family, were accommodated in a house in Istanbul, while his expenses were covered by the government. ${ }^{114}$ In September 1856, both Feyzullah Efendi and Yusuf Efendi were granted monthly salaries (apparently for life) by the Sultan, of 700 and 300 kuruş respectively. ${ }^{115}$ By another imperial decree on 22 October 1856, the two scholars were granted residences. ${ }^{116}$ Among other religious scholars from Kezlev, Ebulhayr Efendi was granted by the Sultan a monthly salary (300 kuruş) and a house, ${ }^{117}$ Ömer Efendi was provided with a dwelling, ${ }^{118}$ and Osman Efendi was granted a monthly salary (200 kuruş). ${ }^{119}$ Upon his own request, Abdullah Efendi, a sheikh of the order of Naqshibandiyya, together with his sons, was sent to the Holy Lands in the Hijaz for the Hajj (pilgrimage). He was granted a salary and the local Ottoman officials were instructed to show him all due respect. ${ }^{120}$ Süleyman Efendi, a sheikh of the Sa'diyya order, was also granted a monthly salary (150 kuruş). ${ }^{121}$ 
Those Crimean Tatars of prominence who were among the mass of immigrants in and around Balçık, apart from their number who came to Istanbul, were also treated more favourably by the government. In fact, clerics and notables who had a large families and entourages asked that the Ottoman authorities treat them more generously than the rest of their compatriots/immigrants since they had more people to care for. This request was granted by the Porte, and instructions were sent to the local officials to the effect that the houses built for such people should be larger than the norm, and they should be constructed, to the extent it was possible, in accordance with the number of members of their households. ${ }^{122}$ Also, in accepting their children into the military, religious, or secular governmental schools, exceptions were made in their favour. ${ }^{123}$

It was not only men of prominence who were granted exceptional favours. In several cases, ordinary Crimean immigrants who petitioned for aid due to their poverty were granted salaries and privileges (such as the payment of their accommodation) too. ${ }^{124}$ There were also cases in which, upon petitioning, large groups were granted one-time or continual payments. ${ }^{125}$ Students who were enrolled in the medreses of Istanbul and were in need were also eligible for imperial bounty. ${ }^{126}$ When they requested it, the old men among the immigrants who wished to travel to the Holy Lands in Hijaz for the Hajj, were granted financial and other assistance. $^{127}$

As of late May 1856, it was estimated that the Crimean immigrants bound to be settled in Rumelia required at least some 3,000 houses, not counting those who were capable of building their houses themselves. Since this was to bring a considerable burden to the state budget, it was deemed to seek the collective work of the local inhabitants. However, as the people of the north-western regions of Rumelia were particularly impaired due to the destruction of the recent war, only a modicum of contribution on their part could be expected or asked. ${ }^{128}$ In order to lighten the burden of the war-torn province of Silistre, the Porte decided to distribute the duty of the building of these houses (each of them with two bedrooms) also to the districts (kazâs) to the west and south, such as those of Vidin, Tirnova, İslimye (Sliven), Ziştovi (Svishtov), Niğbolu (Nikopol), Plevne (Pleven), Lofça (Lovech), Karinâbâd (Karnobat), Selvi (Sevlievo), Aydos (Aytos), Ruskasrı (Rusokastro), etc. Thus, the administrations of these districts, by using their own revenues, would contribute financially and materially to the building of immigrant houses (not necessarily in their own districts). ${ }^{129}$ The local population also contributed to the transportation and settlement of the Crimean Tatar immigrants, by means of aid and donations. For example, the people of Hezargrad (Razgrad) waived the rent for their carts which were used to transport the immigrants from Balçı to the inland, in order to assist in 'our brethren in religion... in a neighbourly and brotherly way'. ${ }^{130}$

In the process, the Porte decided to build a special town as the centre for the immigrant villages. This new town, which would be a noteworthy case of urban settlement in the post-Tanzimat Ottoman history, was to be constructed in the place of the old town of Karasu in central Dobruja. ${ }^{131}$ Karasu was strategically located between the Black Sea port of Köstence (Constanza) and the Danube River, in close proximity to both. It had been a Turkish town of local importance since the sixteenth century. ${ }^{132}$ It had been largely destroyed during the Russo-Ottoman war of 1787-92, and eventually lost its previous stature. Still, its climate and surroundings were 
suitable for settlement. ${ }^{133}$ It was contemplated that while the artisans, tradesmen, and people of other urban professions among the Crimean Tatar immigrants would be settled in the town, those involved in agriculture could inhabit the surrounding villages. ${ }^{134}$ In order to enhance the prosperity of the town, those other than immigrants would also be allowed to build houses, shops, and other buildings there. $^{135}$

Apparently, the idea of building a special town in the place of old Karasu for the Crimean Tatar immigrants was brought forward by the Ottoman officials in the region in April or May 1856. In any case, the idea was granted imperial sanction in May $1856 .^{136}$ The new town was to be modern, to be constructed in a well-planned and organized fashion by specialists. As a matter of fact, it would be in line with the outlook of the Tanzimat period and a prototype for the new Ottoman urbanism based on the European model. To this effect, from its very inception, the project was conducted with meticulous care by the Porte. The new and dynamic approach was also manifest in the very efficient and rapid functioning of the bureaucratic process. ${ }^{137}$ The prominence of the project was underscored by renaming the old Karasu as Mecidiye, that is, in reference to the name of the Sultan Abdülmecid. Obviously, the Sultan was personally overseeing the developments. In September 1856, he approved detailed plans concerning the foundation of the town. ${ }^{138}$

By March 1857, there were about 1,000 homesteads of Crimean Tatar immigrants in Mecidiye. The above-mentioned Abdülveli Bey was appointed director of the town. The villages in Dobruja near Mecidiye where Crimean Tatar immigrants from Kerch and Baydar valley had been settled were administratively united in the form of two townships in accordance with the origin of their inhabitants. Two Crimean Tatar immigrants, Abdullah Efendi and Kasay Mirza, were appointed directors of the townships for the immigrants from Baydar and Kerch respectively. ${ }^{139}$ The importance of Mecidiye was further enhanced by the building of a railroad line between Boğazköy (Cernavoda) and Köstence (Constanza) in 1857 by a British company, being the first of its type in the Ottoman Empire. Mecidiye was located strategically on the line, and, in all probability, the construction of the railroad there was intended to promote the prosperity of Mecidiye. ${ }^{140}$

Among the Crimean Tatar immigrants who were resettled in Rumelia were also some Jews and Christians (mainly or entirely Poles) who had emigrated from the Crimea with them. Although some, if not most, of the Jewish immigrants from the Crimea were settled in Istanbul, when some of them requested land, the Porte decided, in September 1856, to settle them in the Rumelian provinces as they were also 'Crimeans'. ${ }^{141}$ Actually, a few among them had already been in Rumelia (in Varna), but, having faced poverty there, they had returned to Istanbul some time during the summer of $1856 .{ }^{142}$ Still, there were some Jews who stayed in Varna or somewhere else in Rumelia and received both land and salaries. ${ }^{143}$ As for the Poles, they had disembarked in Balçı together with the Crimean Tatars. In accordance with the above-mentioned instructions they were treated equally with the Crimean Tatar immigrants and provisioned with bread. The Poles went to the Tulça district and requested land for farming. In examining their case, the Porte noted that they were not originally Crimeans and many of them were subjects of foreign countries who were of unclear diplomatic status. Since they were not farmers, there were concerns that the Poles intended to sell these lands for a large profit later, instead of 
settling there and engaging in agriculture. Therefore, their requests for land were turned down by the Ottoman government. ${ }^{144}$

By then, in fact, the Porte 'came to believe that a large population was the precondition for economic development as well as for a strong defence against outside enemies'. ${ }^{145}$ Therefore, the settlement and general treatment of Crimean immigrants was quite in line with the current outlook of the Ottoman government. In an imperial decree dated 9 March 1857, it was stated that migration into the Ottoman state was open to anyone who would pay allegiance to the Sultan and his laws. The decree promised not only full religious liberty to the prospective migrants but also free grants of arable land and exemption from all taxes and military service (six years for Rumelian lands, and 12 years for Anatolian lands). The decree was also translated into foreign languages and published in major European newspapers in order to reach out to the public in those countries. ${ }^{146}$

In spite of certain setbacks, the settlement of Crimean Tatar immigrants in Rumelia (especially Dobruja) was completed quite successfully. By March 1857, of the 3,300 homesteads planned for the Crimean Tatars immigrants, 3,030 were already completed in Rumelia. Most of the immigrants had been transferred to these permanent settlements by then. ${ }^{147}$ The immigrants were also supplied with seeds for sowing and draft animals, as well as grain for food when need be, though not without irregularities in the process. ${ }^{148}$ Notwithstanding the well-intentioned approach of the Ottoman government, there is no doubt that things did not proceed as smoothly as appears in the contemporary documents. It is apparent from several petitions of immigrants that there were numerous cases of dereliction in procuring for the immigrants what they were eligible to receive in compliance with the instructions, as well as other failures. In some cases, the final settlement of the migrants who had immigrated during or soon after the Crimean War took several years. ${ }^{149}$ In a report by Ismail Pasha to the Porte in 1858, various shortcomings of the process of the settlement of the immigrants were listed. Such problems included poor quality and diseased draft animals, many of which died, leaving the immigrants unable to cultivate their fields, the low quality of immigrant housing which was also insufficient in numbers, etc. ${ }^{150}$ There were also allegations of corruption involving even the local governors, who found ways of profiting from the settlement of the immigrants. ${ }^{151}$ Still, by and large, the Ottoman government was far better organized and successful in handling this major issue than it had been in previous cases. Evidently, the overwhelming majority of the Crimean immigrants pertaining to the years $1855-57$ were settled in the Balkan lands (mostly in Dobruja), including Istanbul itself. There is no indication of any government sponsored, or noteworthy individual, resettlement in Anatolia or Syria for this period.

On the whole, the Crimean Tatar emigration during the Crimean War might be divided into three phases: a) throughout the year 1855: the evacuation of those refugees who were in urgent need (especially of medical care, shelter, and food) to the Ottoman Empire mostly during the initial stage of the Allied occupation; b) during the first half of 1856 and particularly in April and May: the great exodus of the people in the lands under Allied occupation who were very fearful of Russian reprisals with the withdrawal of Allied (basically Ottoman) troops; c) during the second half of 1856 (extending to 1857): the individual but quite widespread 
emigration of Crimean Tatars from various parts of the peninsula (i.e., not necessarily from the previously Allied-occupied lands) who were motivated by the departure of their compatriots at the end of the war and who simply did not wish to be left behind.

One basic feature of the Crimean Tatar emigration in 1855-56 which distinguished it from the previous ones was that it took place largely from the areas that were under the control of forces fighting against Russia. For the first time since the Russian annexation of the Crimea in 1783, non-Russian armies took control of parts of Crimean soil, and, at least for some time, it seemed to the Crimean Tatars that Russian dominion over their homeland might finally be shaken off. This proved to be a bitter illusion, because the Allies had no such plans or intentions; the ensuing disappointment and consternation led to the movement of thousands of people who were anxious to leave while, they thought, it was still possible.

The Crimean Tatar emigration during and immediately after the Crimean War constitutes one of the major waves of migration to the Ottoman Empire since the Russian annexation of the Crimea in 1783. The total number of Crimean Tatars who emigrated during the years 1855-56 (and probably also 1857) is not available. Based upon the available documentary evidence, it must have been between 20,000-25,000 persons. ${ }^{152}$ Whatever the exact figure might have been, in any case, the departure of tens of thousands of Crimean Tatars from their native soil was a critical loss of population at that time for a steadily-diminishing people like the Crimean Tatars. ${ }^{153}$ However, a far greater and more destructive wave was on the way only some five years later. The great exodus of the 1859-60 Nogay and 1860-61 Crimean emigrations carried away hundreds of thousands of Turkic people of the former Crimean Khanate from their native lands. Consequently, not only the 'Kipchak Steppes', i.e., the plains north of the Black Sea, were virtually depleted of the Nogays, but the Crimean Tatars also lost their majority in the Crimean peninsula, never to recover until this day. Although the Crimean Tatar emigration of 1855-56 seemed to be separate from those between the years 1859 and 1861, the former in fact eventually triggered the latter. There is no doubt that the lack of mutual trust between the Russian authorities and the Crimean Tatar community which had become manifest during the Crimean War contributed a great deal to the emigrations of 1859-61. As a direct consequence of the Crimean War, the Crimean Tatar (as well as Nogay) emigrations between the years 1855 and 1863 constitute the greatest demographic and social catastrophe of the Crimean Tatar people in modern times, with the notable exception of the Soviet mass deportation of 1944 . These emigrations made the Crimean Tatars the primary victims of the Crimean War.

The Crimean Tatar emigration during the Crimean War had an important impact on the Ottoman Empire as well. On the one hand, the Ottoman Empire, the seat of the Caliph of the Muslims of the world, sincerely felt it was its ineluctable duty to accept fellow Muslims who were suffering and in need. In fact, the Ottomans always took pride in their time-honoured tradition of providing shelter for refugees irrespective of their religion or origins, with several notable examples in the recent past. The acceptance of the Crimean Tatars, with all their historical, religious, and ethnic links to the Ottoman state and people, was a most natural affair. After all, they had to abandon their homeland as a result of their avowed sympathies toward the Ottoman Empire and its allies. On the other hand, notwithstanding all the 
complications of dealing with tens of thousands of immigrants, the Porte at the time considered the flux of Muslim immigrants as a positive development which would increase the population (especially its Muslim component) of the empire. In resettling them primarily in their Balkan lands, the Ottoman authorities, among other considerations (such as those of an economic nature), certainly intended to bring about a more favourable demographic balance between the Muslim and Christian populations in that part of their vast empire.

Although the Crimean Tatar emigration during the Crimean War was by no means the first of its kind, it was handled by the Porte in a much more organized and planned fashion than previous instances. The provisioning and settlement of the immigrants was conducted with great care. For the first time in Ottoman history, a special town was founded (or rather re-founded) for the Crimean Tatar immigrants. The migration to the Ottoman Empire in 1855-56 provided a lively precedent for what was to come five years later. The relatively generous approach of the Ottoman government then must have played a certain role in luring the subsequent migrants. Obviously, the Porte considered the Crimean emigration of 1855-56 as an exceptional occurrence which would not continue in the ensuing years. Of course, the Ottoman authorities would be overwhelmed during the first half of the 1860 s with the simultaneous and immense waves of immigrations from the Crimea, the Caucasus, and the 'Kipchak Steppes', and would by no means be in a position to provide the same degree of aid and care to the immigrants. Still, the experience of 1855-56 would help the Porte considerably in handling the huge-scale immigrations during 1860 s.

\section{Notes}

1. For the 'Greek Project', see E. Hösch, 'Das sogenannte griechische Project Katharinas II. Ideologie und Wirklichkeit der russischen Orientpolitik in der zweiten Hälfte des 18. Jahrhunderts', Jahrbücher für Geschichte Osteuropas, Vol.12 (1964), pp.168-206; H. Ragsdale, 'Evaluating the Traditions of Russian Aggression: Catherine II and the Greek Project', Slavonic and East European Review, Vol.66, No.1 (Jan. 1988), pp.91-117.

2. In spite of the fact that there remains much to be unearthed and analysed about Crimean Tatar emigrations, as well as the process of their resettlement in the Ottoman Empire, there exist quite a few works on the matter, covering the subject directly or within the context of other issues. For some notable examples, see A.I. Markevich, 'Pereselenie krymskikh tatar v Turtsiiu v sviazi s dvizheniem naseleniia v Krymu', Izvestiia Akademii Nauk Soiuza Sovetskikh Sotsialisticheskikh Respublik. Otdelenie Gumanitarnykh Nauk, 7th Series (Leningrad, 1928), pp.375-405; A. Özenbaşl1, Carlık Hakimiyetinde Ktrım Faciast yahud Tatar Hicretleri (Akmescit/Simferopol, 1925); M. Pinson, 'Russian Policy and the Emigration of the Crimean Tatars to the Ottoman Empire, 1854-1862', Güney-Doğu Avrupa Arastırmalart Dergisi (Istanbul), No.1 (1972), pp.37-56; Nos.2-3 (1973-74), pp.101-14; A.W. Fisher, 'Emigration of Muslims from the Russian Empire in the Years after the Crimean War', Jahrbücher für Geschichte Osteuropas (Stuttgart), New Series, Vol.35, No.3 (1987), pp.356-71; B.G. Williams, 'Hijra and Forced Migration from Nineteenth-Century Russia to the Ottoman Empire. A Critical Analysis of the Great Crimean Tatar Emigration of 1860-1861', Cahiers du Monde russe (Paris), Vol.41, No.1 (Jan. - March 2000), pp.79-108; E.F. Gözaydın, Kırım. Kırım Türklerinin Yerleşme ve Göcmeleri (Istanbul, 1948); A. Saydam, Kırım ve Kafkas Göcleri (1856-1876) (Ankara, 1997); S. Erkan, Kırım ve Kafkasya Göcleri (1878-1908) (Trabzon, 1996). Apart from these works of more or less general nature, there are other publications (especially in Russian) dwelling on certain waves or specific aspects of the emigrations.

3. S. Lapitskaia, 'Zavoevanie i kolonizatsiia Kryma tsarizmom', Istoricheskii Zhurnal, No.7 (June 1937), p.52. 
4. A. Krichinskii (ed.), Ocherki russkoi politiki na okrainakh, Vol.1, $K$ istorii religioznykh pritesnenii krymskikh tatar (Baku, 1919), pp.68-72.

5. Ibid., pp.74-5; N.F. Dubrovin, Istoriia krymskoi voiny i oborony Sevastopolia, Vol.1 (St. Petersburg, 1900), p.280. Pestel's sympathetic feelings toward the Crimean Tatars were displayed on other occasions too. For example, during the initial stages of the war, he was not disposed to take stern measures against the Crimean Tatars, who were accused by a group of Russian noblemen of engaging in 'revolts'. V.S. Rakov, Moi vospominaniia o Yevpatorii v epokhu Krymskoi voiny 18531856 g.g. (Yevpatoriia/Kezlev, 1904), p.24.

6. Dubrovin, p.280.

7. Ibid., p.284.

8. 'Gonenie na krymskikh tatar', Kolokol (London), No.117 (22 Dec. 1861), p.973; E. Todleben, 'O vyselenii tatar iz Kryma v 1860 godu. Zapiska general-adiutanta E.I. Totlebena', Russkaia starina, No.6 (June 1893), p.532.

9. [S.J.G. Calthorpe], Letters from Head-Quarters; or, the Realities of the War in the Crimea, Vol.1 (London, 1856), pp.137-9; Rakov, p.15.

10. S.M. Eardley-Wilmot, Life of Vice-Admiral Edmund Lord Lyons (London, 1898), p.215.

11. [Calthorpe], p.139.

12. C.L.B. de Bazancourt, The Crimean Expedition, to the Capture of Sebastopol. Chronicles of War in the East, from its Commencement to the Signing of the Treaty of Peace, Vol.1 (London, 1856), p.196; A.W. Kinglake, The Invasion of the Crimea; its Origin, and an Account of its Progress down to the Death of Lord Raglan, Vol.2 (Edinburgh and London, 1888), pp.350-51; A.I. Markevich, Tavricheskaia guberniia vo vremia Krymskoi voiny po arkhivnym materialam (Simferopol/Akmescit, 1994), p.14; Rakov, p.19.

13. Russian War, 1855. Black Sea. Official Correspondence (London, 1945), p.427; Rakov, p.19.

14. Dubrovin, p.289.

15. Golenkovskii, Zapiski deistviiakh Yevpatoriiskogo otriada v Krymu v 1854, 1855 i 1856 godakh (St. Petersburg, 1856), pp.4-5; T.C. Başbakanlık Osmanlı Arşivi [The Ottoman Archives of the Prime Ministry of the Republic of Turkey; hereafter to be cited as BOA], Irade-Dahiliye, Dosya No.369, Gömlek No.24397.

16. Russian War, 1855. Black Sea. Official Correspondence, p.428.

17. Ibid., pp.428-431; Eardley-Wilmot, p.233.

18. G.P. Levitskii, 'Pereselenie tatar iz Kryma v Turtsiiu', Vestnik Yevropy (St. Petersburg), Vol.17, No.10 (Oct. 1882), p.624.

19. E. Hamley, The War in the Crimea (Edinburgh, 1910), p.41; T. Royle, Crimea. The Great Crimean War 1854-1856 (New York 2000), p.207.

20. For a few of those individuals who subsequently emigrated to the Ottoman Empire, see BOA, IradeMeclis-i Vâlâ, Dosya No.368, Gömlek No.16159 and Dosya No.351, Gömlek No.15310; IradeDahiliye, Dosya No.368, Gömlek No.24358, Dosya No.367, Gömlek No.24297, and Dosya No.53, Gömlek No.26166; A.MKT.NZD., Dosya No.212, Gömlek No.22 and Dosya No.200, Gömlek No.58.

21. Rakov, p.22.

22. Markevich, 'Pereselenie krymskikh tatar v Turtsiiu v sviazi s dvizheniem naseleniia v Krymu', p.394.

23. F. Stulli, 'Iz epokhi Krymskoi voiny', Vestnik Evropy (St. Petersburg), Vol.4 (1876), pp.444, 448-9.

24. Todleben, p.533.

25. B.M. Vol'fson, 'Emigratsiia Krymskikh tatar v 1860 g.', Istoricheskie zapiski (Moscow), No.9 (1940), pp.186-7.

26. Markevich, p.393.

27. Vol'fson, p.187.

28. Levitskii, pp.605-6; V.K. Kondaraki, V Pamiat' stoletiia Kryma. Vol.2, Etnografiia Tavridy (Moscow, 1883), part 2, p.150. The number of Crimean Tatars exiled to Kursk was more than 100. In the fortress jail of Yekaterinoslav, there were 78 Crimean Tatars. While 49 were accused of plundering, 29 were kept without any charges whatsoever. Markevich, Tavricheskaiia guberniia, p.32. Among such people, who were put in chains, were even 90-year-old men. M. Goldenberg, 'Krym i Krymskie tatary', Vestnik Yevropy (St. Petersburg), Vol.18, No.11 (November 1883), p.72.

29. Markevich, p.31. 
30. Ibid., p.34.

31. P. Warner, The Crimean War. A Reappraisal (New York, 1973), p.120.

32. 1 verst: $1.06 \mathrm{~km}$.

33. Rossiiskii Gosudarstvennyi Voenno-Istoricheskii Arkhiv [Russian State Military History Archive] (Moscow), f.9196, op.4/254 sv.11, d.59, 1.1 and f.846, op.16, d.5948, 1.137; Markevich, p.34.

34. E. Todleben (ed.), Opisanie oborony g. Sevastopolia, Vol.1 (St. Petersburg, 1863), p.602.

35. L.I. Dubinina, 'Sobytiia v Yevpatorii i uezde v period Krymskoi voyny', Izvestiia Krymskogo respublikanskogo kraevedcheskogo muzeia (Simferopol/Akmescit), No.12 (1995), p.3.

36. Todleben, 'O vyselenii tatar', p.532.

37. Dubinina, p.3.

38. [S.J.G. Calthorpe], Letters from Head-Quarters; or, the Realities of the War in the Crimea, Vol.2 (London, 1856), pp.170-71.

39. Golenkovskii, p.7.

40. [Calthorpe], Vol.2, p.171.

41. Golenkovskii, p.8.

42. Todleben, 'O vyselenii tatar', p.533.

43. A. Özenbaşlı, Çarlık Hâkimiyetinde Kırım Faciası yahud Tatar Hicretleri (Simferopol/Akmescit, 1925), p.73.

44. Golenkovskii, p.8.

45. Eardley-Wilmot, p.282.

46. Ibid.

47. BOA, Irade-Dahiliye, Dosya No.309, Gömlek No.19757.

48. V.N. Gurkovich, 'Za veru, Tsar i otechestvo', Yevpatoriyskaia zdravnitsa, 7 Oct. 1997; 'The Story of the Campaign. Written in a Tent in the Crimea - Part V', Blackwood's Edinburgh Magazine (Edinburgh), Vol.77, No.474 (April 1855), p.498. It is noteworthy that while there were Crimean Tatar volunteers among the Allied forces, Greek volunteers from the Ottoman lands served in the Russian army during the battle of Kezlev. N.F. Dubrovin (ed.), Materialy dlia istorii Krymskoi voiny i oborony Sevastopolia, Vol.5 (St. Petersburg, 1874), pp.310-12; Rakov, p.45.

49. BOA, Irade-Dahiliye, No.20488; A.MKT.MHM., Dosya No.68, Gömlek No.51; A.AMD, Dosya No.64, Gömlek No.13.

50. BOA, Irade-Dahiliye, No.20488.

51. BOA, A.AMD, Dosya No.58, Gömlek No.9.

52. A.A. Galichenko, 'Iuzhnyi bereg Kryma v period Krymskoi voiny', Izvestiia Krymskogo respublikanskogo kraevedcheskogo muzeia (Simferopol/Akmescit), No.12 (1995), p.9.

53. A. Sterling, The Highland Brigade in the Crimea (Minneapolis, MN, 1995), p.223.

54. C.E. Vulliamy, Crimea. The Campaign of 1854-56 (London, 1939), p.120.

55. Tsentral'nyi Gosudarstvennyi Arkhiv Avtonomnoi Respubliki Krym [Central State Archives of the Crimean Autonomous Republic; hereafter to be cited as TsGAARK] (Akmescit/Simferopol), f.26, op.4, delo 1585 .

56. TsGAARK, f.26, op.4, delo 1624 and 1667.

57. J.H. Skene, With Lord Stratford in the Crimean War (London, 1883), p.218.

58. I. Voronov, 'Zaniatie Kerchi nepriiatelem v Krymskoiu kampaniiu', Russkaia starina (St. Petersburg), No.5 (May 1908), pp.417-19; N.F. Dubrovin, Istoriia krymskoi voiny i oborony Sevastopolia, Vol.3 (St. Petersburg, 1900), p.178; A.W. Kinglake, The Invasion of the Crimea; its Origin, and an Account of its Progress down to the Death of Lord Raglan, Vol.9 (Edinburgh and London, 1888), pp.52-8. General Todleben states that among the plunderers in Kerch were not only Crimean Tatars, but also Greeks, Armenians, Jews, and Russians. Todleben, 'O vyselenii tatar', p.533.

59. S. Besbelli, 1853-1856 Osmanlı-Rus ve Kırım Savassı Deniz Harekâtı (Ankara, 1977), p.84.

60. The National Archives (London), F.O. 424/15, p.128.

61. Ibid.

62. BOA, A.AMD., Dosya No.62, Gömlek No.44.

63. BOA, Irade-Dahiliye, Dosya No.322, Gömlek No.20915.

64. BOA, Irade-Dahiliye, Dosya No.351, Gömlek No.23121.

65. BOA, A.DVN., Dosya No.107, Gömlek No.59. Later, these Jewish refugees from Kerch, being Ashkinazim, notified the Porte of their sectarian difference from the resident Jewish community of 
Istanbul who were Sefardim, and requested that they be allowed to have their own rabbis. This request was granted by the Sultan on 7 August 1856. BOA, Irade-Hariciye, Dosya No.133, Gömlek No.6857.

66. BOA, Irade-Hariciye, Dosya No.125, Gömlek No.6264; A.MKT.NZD, Dosya No.165, Gömlek No.66.

67. BOA, Irade-Meclis-i Vâlâ, Dosya No.351, Gömlek No.15310.

68. J.C. Hurewitz (ed.), Diplomacy in the Near and Middle East, Vol.1 (Princeton, NJ, 1956), p.154.

69. BOA, Irade-Meclis-i Mahsus, Dosya No.7, Gömlek No.266.

70. Ibid.

71. K.H. Karpat, 'Ottoman Urbanism: the Crimean Emigration to Dobruca and the Founding of Mecidiye, 1856-1878', International Journal of Turkish Studies (Madison, WI), Vol.3, No.1 (Winter 1984-85), p.3.

72. Markevich, p.395.

73. Todleben, 'O vyselenii tatar', pp.538-9.

74. Ibid. Apparently, as their stay in Balçık was prolonged, the immigrants were given extra rations. BOA, ML.CRD, Defter No. 1750.

75. BOA, Irade-Meclis-i Mahsus, Dosya No.7, Gömlek No.266.; A.AMD., Dosya No.70, Gömlek No.31.

76. Dubinina, p.4.

77. Markevich, p.222.

78. For example, only 20 families were left in the village of Sak, to the south of Kezlev. L.D. Iudina, 'Sakskaia volost' vo vremia Krymskoi voiny', Konferentsiia posviashchennaia 145-letiiu okonchaniia Krymskoi voiny 1853-1856 gg. (Simferopol/Akmescit, 2001), p.88.

79. BOA, Irade-Dahiliye, Dosya No.345, Gömlek No.22748.

80. BOA, A.MKT.NZD., Dosya No.186, Gömlek No.58.

81. Markevich, p.222.

82. BOA, A.MKT.NZD., Dosya No.186, Gömlek No.58. It is not clear whether these 64 Jews who were sent to Rumelia belonged to the previously mentioned 80 Jewish families who had been temporarily settled in Beyoğlu (Istanbul) by September 1855. See, BOA, A.DVN., Dosya No.107, Gömlek No.59.

83. Todleben, 'O vyselenii tatar', p.534.

84. BOA, A.MKT.UM., Dosya No.237, Gömlek No.64.

85. Markevich, p.222.

86. Ibid., p.223.

87. Commenting on the emigration of the Crimean Tatars and on the resettlement of the Crimea with other peoples, a Russian officer observed to a Frenchman, 'You have given us a lesson, for which we thank you.' Sterling, p.244.

88. BOA, A.MKT.NZD., Dosya No.186, Gömlek No.58. Markevich wrote that, as of 22 April 1856, the number of those Crimean Tatars who had departed from Balaklava were 4,500. Markevich, 'Pereselenie Krymskikh tatar', p.395.

89. Galichenko, p.9.

90. BOA, A.MKT.NZD., Dosya No.186, Gömlek No.58.

91. BOA, ML.CRD., Defter No.1750.

92. In my own expeditions to Crimean Tatar immigrant villages in Turkey, I have located several individuals whose origins went back to the immigration of 1856. For instance, the Crimean Tatars currently living in the village of Büyük Doğanca (Keşan, Edirne) state that their ancestors (primarily from the village of Duvanköy, Bahçesaray) left the Crimea in November 1856 for Varna. Ancestors of the residents of the village of İzzettin (Çatalca, Istanbul) were also from the villages of Bahçesaray, who had departed from the Crimea for Istanbul in October 1856.

93. Todleben, 'O vyselenii tatar', pp.539-40. Mehmed Bey Bolatukov had actively contributed in the war effort of Russia and he had been highly praised by local Russians for his protection of all people in need regardless of religion in the Kezlev region. Rakov, p.16.

94. Todleben, 'O vyselenii tatar', pp.540-41.

95. BOA, A.MKT.NZD., Dosya No.182, Gömlek No.55.

96. BOA, A.MKT.UM., Dosya No.234, Gömlek No.1.

97. BOA, A.MKT.UM., Dosya No.235, Gömlek No.50, Dosya No.233, Gömlek No.67, and Dosya No.234, Gömlek No.1. 
98. BOA, Irade-Meclis-i Mahsûs, Dosya No.7, Gömlek No.283.

99. BOA, ML.CRD., Defter No.1750.

100. BOA, Irade-Meclis-i Mahsûs, Dosya No.7, Gömlek No.283.

101. BOA, ML.MSF., Defter No.11164.

102. BOA, A.MKT.UM., Dosya No.234, Gömlek No.1 and A.MKT.NZD., Dosya No.186, Gömlek No.58.

103. BOA, A.MKT.UM., Dosya No.235, Gömlek No.50.

104. BOA, Irade-Meclis-i Mahsûs, Dosya No.7, Gömlek No.283.

105. BOA, Irade-Dahiliye, Dosya No.343, Gömlek No.22622.

106. BOA, A.MKT.NZD., Dosya No.185, Gömlek No.28.

107. There are several reports of individual groups of migrants sailing to Istanbul by their own means after June 1856, such as a group of 17 households from Kezlev (BOA, Irade-Dahiliye, Dosya No.347, Gömlek No.22878), a group of 112 people (A.MKT.NZD., Dosya No.187, Gömlek Nos.13/1 and 13/ 2), a group of 62 people from Kezlev and Kerch (A.MKT.NZD., Dosya No.187, Gömlek No.13/3), a group of 45 people from Kezlev (A.MKT.NZD., Dosya No.187, Gömlek No.40 and A.MKT.MVL., Dosya No.79, Gömlek No.53), a group of 92 people (A.MKT.NZD., Dosya No.188, Gömlek No.39), a group of 96 people from the Crimea (their places of origin in the Crimea was not specified) (IradeDahiliye, Dosya No.352, Gömlek No.23206), a group of 81 people from Kezlev (Irade-Dahiliye, Dosya No.351, Gömlek No.23121), 227 people from Kezlev (Irade-Dahiliye, Dosya No.349, Gömlek No.23039), a group of 92 people (A.MKT.UM., Dosya No.248, Gömlek No.77), 25 people from Kerch via Anapa (Írade-Dahiliye, Dosya No.361, Gömlek No.23924), a group of 58 people (IradeDahiliye, Dosya No.362, Gömlek No.23951) (It is possible that some of the above-mentioned people were repeatedly recorded in the documents).

108. Irade-Dahiliye, Dosya No.362, Gömlek No.23951.

109. BOA, Irade-Meclis-i Vâlâ, Dosya No.351, Gömlek No.15310; Irade-Dahiliye, Dosya No.363, Gömlek No.24015.

110. BOA, A.MKT.NZD., Dosya No.182, Gömlek No.55; A.MKT.UM., Dosya No.209, Gömlek No.48.

111. BOA, Irade-Dahiliye, Dosya No.368, Gömlek No.24358.

112. BOA, A.MKT.NZD., Dosya No.209, Gömlek No.11 and Dosya No.212, Gömlek No.22; A.MKT.UM., Dosya No.287, Gömlek No.44; Irade-Dahiliye, Dosya No.369, Gömlek No.24397 and 24297; İrade-Meclis-i Vâlâ, Dosya No.368, Gömlek No.16159.

113. BOA, A.MKT.NZD., Dosya No.185, Gömlek No.26. Feyzullah Efendi is inaccurately cited in the Ottoman documents as the 'Mufti of Gözleve [Kezlev].' This could not be the case, as in accordance with the tsarist practice there was only one official mufti, who had his seat in Akmescit (Simferopol), and there were kadis in the major towns, including Kezlev.

114. BOA, A.MKT.NZD., Dosya No.186, Gömlek No.98.

115. BOA, A.MKT.NZD., Dosya No.193, Gömlek No.58.

116. BOA, Irade-Dahiliye, Dosya No.357, Gömlek No.23603.

117. BOA, Irade-Dahiliye, Dosya No.349, Gömlek No.23018 and Dosya No.357, Gömlek No.23586.

118. BOA, A.MKT.UM., Dosya No.205, Gömlek No.6; Irade-Dahiliye, Dosya No.373, Gömlek No. 24720.

119. BOA, Irade-Dahiliye, Dosya No.364, Gömlek No.24129.

120. BOA, A.MKT.NZD., Dosya No.194, Gömlek No.23; A.MKT.UM., Dosya No.252, Gömlek No.85.

121. BOA, Irade-Dahiliye, Dosya No.360, Gömlek No.23817.

122. BOA, A.MKT.NZD., Dosya No.186, Gömlek No.92.

123. BOA, Irade-Dahiliye, Dosya No.345, Gömlek No.22727.

124. For such cases, see BOA, A.MKT.NZD., Dosya No.198, Gömlek No.23; A.MKT.MVL, Dosya No.84, Gömlek No.41 and Dosya No.79, Gömlek No.53; Irade-Dahiliye, Dosya No.360, Gömlek No.23795, Dosya No.368, Gömlek No.24390, and Dosya No.360, Gömlek No.23809; Irade-Meclis- $i$ Vâlâ, Dosya No.410, Gömlek No.17814.

125. BOA, Irade-Dahiliye, Dosya No.360, Gömlek No.23803.

126. BOA, Irade-Dahiliye, Dosya No.362, Gömlek No.23969 and Dosya No.360, Gömlek No.23824; A.MKT.NZD., Dosya No.209, Gömlek No.91 and Dosya No.213, Gömlek No.50; A.MKT.MVL., Dosya No.86, Gömlek No.74.

127. BOA, A.MKT.UM., Dosya No.278, Gömlek No.36.

128. BOA, Irade-Dahiliye, Dosya No.346, Gömlek No.22844. 
129. BOA, A.MKT.UM., Dosya No.240, Gömlek No.74.

130. BOA, Irade-Dahiliye, Dosya No.352, Gömlek No.23211.

131. For the details of the founding of the new town of Mecidiye in the place of Karasu, see Karpat, pp.125.

132. For the 'pre-Mecidiye' history of Karasu, see A.L.-Ş. Lapuşan, Medgidia Carasu (Constanza, 1996), pp.34-67.

133. BOA, Irade-Meclis-i Mahsûs, Dosya No.7, Gömlek No.283.

134. Ibid.

135. BOA, A.AMD, Dosya No.67, Gömlek No.65; A.MKT.NZD., Dosya No.192, Gömlek No.65; IradeDahiliye, Dosya No.352, Gömlek No.23226.

136. BOA, Irade-Meclis-i Mahsûs, Dosya No.7, Gömlek No.283.

137. Karpat, pp. $9-10$.

138. Ibid., pp.1-2.

139. BOA, İrade-Meclis-i Vâlâ, Dosya No.368, Gömlek No.16141.

140. Karpat, p.10.

141. BOA, A.MKT.NZD., Dosya No.194, Gömlek No.47; Irade-Dahiliye, Dosya No.361, Gömlek No.23899.

142. BOA, Irade-Dahiliye, Dosya No.351, Gömlek No.23121.

143. BOA, A.MKT.UM., Dosya No.265, Gömlek No.66.

144. BOA, A.MKT.UM., Dosya No.270, Gömlek No.79.

145. K. Karpat, Ottoman Population 1830-1914. Demographic and Social Characteristics (Madison, WI, 1985), p.62.

146. Ibid.

147. BOA, A.MKT.UM., Dosya No.270, Gömlek No.79 and A.MKT.MVL., Dosya No.86, Gömlek No.15.

148. BOA, Irade-Meclis-i Vâlâ, Dosya No.368, Gömlek No.16159.

149. For instance, in November 1861, a group of migrants from Kezlev who had arrived in the Ottoman Empire during or soon after the Crimean War, and who were not settled, petitioned the Porte for settlement in the village of Sazlıbosna near Istanbul, where their relatives were residing. They had spent five years in penury in Istanbul. BOA, A.MKT.NZD., Dosya No.386, Gömlek No.47 and A.MKT.UM., Dosya No.528, Gömlek No.72.

150. D.C. Cuthell, 'The Muhacirin Komisyonu: An Agent in the Transformation of Ottoman Anatolia, 1860-1866' (Ph.D. dissertation, Columbia University, New York, 2005), p. 100.

151. Ibid., pp.99-100.

152. Given the available official figures, the number of the emigrants could not be fewer than 20,000 . The unrecorded, individual, and yet-inaccessible figures may well account for several thousand more including the years 1856-57. So far, it seems that all the figures presented for the total numbers in this wave of emigration in the scholarly literature are rough estimates rather than official or unofficial statistics. See Pinson, p.44; Williams, p.88.

153. In 1859, the population of the Crimean Tatars (together with the Nogays residing in the mainland part of the Tauride guberniia) was estimated as 295,357 . 'Kratkoe istoriko-statisticheskoe obozrenie Tavricheskoi gubernii', in K.V. Khanatskii (ed.), Pamiatnaia kniga Tavricheskoi gubernii, Vol.1 (Akmescit/Simferopol, 1867), p.196. 